\title{
Çocuklarda üriner sistem taş hastalıkları
}

\section{Childhood urinary system stone diseases}

\author{
Serkan TURSUN ${ }^{1 *}$, Cansu ÇELIK'1 ${ }^{1}$ Banu ÇELIKEL ACAR²
}

${ }^{1}$ Kırıkkale Üniversitesi Tıp Fakültesi, Çocuk Sağlığı ve Hastalıkları AD, Kırıkkale

${ }^{2}$ Kırıkkale Üniversitesi Tıp Fakültesi Çocuk Sağlığı ve Hastalıkları AD, Çocuk Nefroloji BD, Kırıkkale, TÜRKIYE

\section{öz}

Çocuklarda üriner sistem taş hastalıkları son yıllarda çok daha fazla tanı almaya başlamıştır. Erken tanı, ortaya çıkabilecek ciddi morbiditeleri önlemek açısından önem taşır. Çocuklarda taş oluşumu altta yatan anatomik veya metabolik bir bozukluktan kaynaklanabilir. Klinik bulgular, çocuğun yaşı, taşın lokalizasyonu ve büyüklüğü ve altta yatan hastalığa bağlı olarak değişmektedir. Tedavide altta yatan nedenin ortadan kaldırılması önemlidir. Tedavi sonrasında yeni taş oluşumunun önlenmesi için yeterli sıvı alımının sağlanması, diyet ve yaşam tarzının düzenlenmesi gereklidir.

Anahtar Kelimeler: Çocuk, üriner sistem, taş

\section{ABSTRACT}

Currently, the diagnosis of pediatric stone disease are increasing. Early diagnosis is essential to prevent possible serious morbidities. Pediatric stone disease can be related to an underlying anatomical or metabolic disorder. Clinical findings are variable and they differ related to the child's age, localization of stone, size and underlying diseases. It is important to eliminate the underlying reason in the treatment of this condition. The clinician should warn families about inadequate fluid intake, dietary changes and lifestyle changes to prevent new stone formations after the initial treatment,.

Keywords: Child, urinary system, stone 


\section{Giriş}

Çocuklarda son yıllarda tanı olanaklarının artışı ve toplumdaki değişen yaşam tarzı (sedanter yaşam, karbonhidrat ve tuz ağırlıklı beslenme) nedeniyle insidansı artış gösteren üriner sistem taş hastalıklarının (ÜSTH) erken fark edilmesi ve taş hastalığının etiyolojisine uygun tanı ve tedavinin uygulanması hastanın yaşam kalitesini düzeltmek ve ileride ortaya çıkabilecek morbiditeleri önlemek açısından kritik önem taşımaktadır. Ülkemizde çocuklardaki böbrek yetmezliği vakalarının \%8'inden ÜSTH sorumludur. Bu oran Güneydoğu Anadolu bölgesinde \%22'lere ulaşmaktadır [1,2].

Bir taraftan taş oluşumuna zemin hazırlayan anatomik ve metabolik bozuklukluklara erişkinden daha sık rastlanması, diğer taraftan da özellikle küçük çocuklarda genellikle karın ağrısı gibi özgül olmayan ve üriner sistem enfeksiyonunu taklit eden semptomlarla ortaya çıkabilmesi ve en önemlisi altta yatan sorunun tespit ve tedavisinin uzun dönem morbiditelerin önlenebilmesinde kilit rolünün olması, çocukluk çağı üriner sistem taş hastalıklarına ayrı bir önem verilmesini gerekli kılmaktadır.

\section{Epidemiyoloji}

Üriner sistem taş hastalığı, daha önceleri özellikle gelişmekte olan ülkelerin bir sağlık sorunu olarak görülmekteyken son yıllarda yapılan epidemiyolojik çalışmalar gelişmiş toplumlarda da insidansının belirgin olarak arttığını göstermektedir [3]. Ülkemizin de içinde bulunduğu, Balkanlar'dan başlayıp Pakistan ve Kuユzey Hindistan'a uzanan coğrafyada böbrek taşları endemik olarak görülürken Afrika kökenlilerde ise nadirdir [4]. Çocuklarda üriner sistem taş hastalıkları erişkinlere kıyasla nadir görülürler, çocuk taş hastaları tüm taş hastalarının \%2-3 ünü oluşturmaktadır ve çoğunlukla bu vakalar anatomik veya metabolik bir bozukluğun taşa oluşturduğu yatkınlıkla ilişkilidir. Taşlar 2/3 oranında böbrekte lokalize iken, daha büyük çocuklarda üreter taşları daha sık görülmektedir. Bazı çalışmalar erkek çocuklarda daha sık taş görüldüğünü göstermiş olsa da, genele bakıldığında iki cinsiyet arasında fark gözükmemektedir. Üriner sistem taşları 2 yaşından önce oldukça nadir olmakla birlikte, her yaşta oluşabilmektedir. Ortalama görülme yaşı kızlarda 7, erkeklerde 5 yaş civarıdır [4]. Yaş aralığı arttıkça ÜSTH olanlarda kızların oranı artış göstermektedir. Erkek çocuklar arasında taş oluşumu ile sonuçlanabilecek üriner sistemin anatomik ve fonksiyonel bozuklukları, kızlara oranla daha sık görülür. Kızların puberteye yaklaşmasıyla idrar yolu enfeksiyonu insidansı artmakta ve bu da yaşlara göre cinsiyetlerdeki sıklığın kızlar yönünde artışını açıklayabilir [5].
Son yıllarda yapılan bazı çalışmalarda çocukluk çağı ÜSTH insidansında belirgin bir artış olduğu dikkati çekmektedir [3]. Bununla birlikte pediatrik popülasyondaki üriner sistem taş hastalığı insidansının artışının yetişkin popülasyondaki artış ile uyumlu seyrettiğinin görülmesi, pediyatrik üriner sistem taş hastalıkları riskinin yıllar içinde artış göstermesinden çok tanı tekniklerinin gelişmesi nedeniyle tanı koyma oranının arttığını düşündürmektedir. Radyolojik tekniklerde yaşanan gelişmeler önceki yıllarda gözden kaçırabilen asemptomatik olguların ve küçük yaştaki çocuklardaki taş vakalarının da tanı alabilmesini sağlamıştır.

\section{Etiyopatogenez}

Üriner sistem taşlarının oluşumunda, kristalize olup böbrek ve üreterlerde birikebilecek tuzların (kalsiyum, oksalat, fosfat, ürik asit) fazla alımı veya atılmalarının azalması veya bu tuzlara bağlanarak organizmadan uzaklaştıran doğal baskılayıcılar diyebileceğimiz ürünlerin (sitrat, magnezyum, fitat ve pirofosfat iyonları) azlığının rol oynadığı düşünülmektedir. Böbreklerde bu maddelerin absorbsiyon ve ekskresyon sürecinde dengesizliğe yol açabilecek konjenital ve yapısal anomaliler, enfeksiyonlar, ilaçlar, metabolik bozukluklar (hiperkalsiüri, hiperoksalüri, hiperürikozüri, sistinüri vb.) gibi her türlü durum taş oluşumu için bir risk faktörü olarak karşımıza çıkmaktadır (Tablo 1). Yapılan araştırmalarda üriner sistem taş hastalığı olan çocukların \%75'inde altta yatan bir risk faktörü belirlenmiştir [6]. Kalsiyum oksalat taşları üriner sistem taşlarının içerik olarak dağılımı incelendiğinde en sık karşılaşılan türüdür [7]. Sıkca karşılaşılan diğer taş içerikleri ise kalsiyum fosfat taşları, sitrüvit, ürik asit ve sistin taşları olarak sayılabilir.

\section{Hiperkalsiüri}

Metabolik bir bozukluk nedeniyle üriner sistem taşı oluşan hastalarda en sık tespit edilen problem hiperkalsiüridir. Hiperkalsiüri 2 yaşından büyük bir çocukta günlük kalsiyum atılımının 4 mg/kg'dan fazla olması şeklinde tanımlanır (Tablo 2). Yirmidört saatlik idrar toplamak çocuk hastada bazen zor olabileceği için hiperkalsiüri tespitinde idrar kalsiyum/ kreatinin oranının 0,21 den fazla olması da spesifik olmasa da sensitif bir belirteç olarak kullanılabilir [8]. Barsaklardan emilim, böbrek tübüllerinden atılım ve kemik rezorbsiyonunun miktarı idrarla atılan kalsiyum miktarını etkiler. Pek çok genetik ve çevresel faktörün hiperkalsürinin oluşmasında etkisi vardır. Örneğin dehidratasyon, idrar miktarının, atılan kalsiyumun çözünebileceği miktarın altına düşmesine böylece kalsiyumun presipite olmasına sebep olur. Immobilizasyon gibi kemik yıkımını artıran durumlar kana karışan kalsiyum miktarını arttıracaktır. Loop diüretikler, glukokortikoidler gibi ilaçların 
kullanımı, D vitamini fazlalığı gibi faktörler de idrarla kalsiyum atılımını etkiler.

\section{Hiperoksalüri}

Hiperoksalüri sık görülen metabolik bozukluklardandır. Çoğunlukla oksalat, atılımı artan kalsiyum ile birlikte çöktüğü için taş hastalıklarında idrarda fazladır. Ancak idiyopatik primer hiperoksalüri gibi nadir hastalıklarda, yağ malabsorbsyonu olan çocuklarda vücutta artan yağın kalsiyumu bağlamasıyla, oksalatın fazlası kalsiyuma bağlanıp atılamaz. Bu gibi durumlarda da oksalat taşları görülebilir. Ayrıca metanol ve etilen glikol de vücutta oksalata metabolize olurlar, bu maddelerin fazla alımı da oksalat taşlarının oluşumu ile sonuçlanabilir.

\section{Hiperürikozüri}

Ürik asit taşları taş hastalığı olan çocukların \%2-8'ini oluşturur. Yaşa göre normal atılım miktarı değişkenlik göstermektedir. Devamlı asidik idrar atılımı, ürik asit taşlarının oluşumuna zemin hazırlar. Ürik asit genelde diğer kristal tipleriyle birlikte çöker. Tek başına taş oluşturması pediatrik vakalarda nadirdir. Bu vakalar da ürik asit oluşumunun arttığı; tümör lizis sendromu, lenfoproliferatif ve myeloproliferatif hastalıklar, nadiren de Lesch-Nyhan hastalığı, glikojen depo hastalıkları gibi hastalıklarla ilişkili olurlar [9].

\section{Sistinüri}

Sistin taşları renal tübüllerden dibazik aminoasitler sistin, lizin, arjinin, ornitinin geri emilememesi ile karakterize otozomal resesif bir hastalık olan sistinüriden kaynaklanır. Tekrarlayan üriner sistem taşları ve ailede taş hastalığı olan hastalarda mutlaka ayırıcı tanıda akılda tutulması ve araştırılması gerekmektedir.

\section{Hipositratüri}

Sitrat kalsiyumu bağlayarak suda çözünebilen bir forma dönüştürür. Böylece kalsiyumun taş oluşumuna neden olabilecek diğer iyonlarla bağlanmasını engeller ve tübüllerde birikimini önler.

\section{Diğer Metabolik Sebepler}

Hayvansal protein ağırıklı beslenme, ketojenik diyet, kistik fibrozis, furosemid, asetozalamid, allopurinol gibi üriner ekskresyonu arttıran ilaçlar, bazı pürin ve pirimidin metabolizma bozuklukları üriner sistem taş oluşumuna yatkınlık yaratabilen diğer diğer metabolik nedenler olarak sıralanabilir. Anamnezde mutlaka sorgulanmalıdır.

\begin{tabular}{|c|c|c|c|}
\hline \multicolumn{2}{|l|}{ Hiperkalsüri Nedenleri } & \multicolumn{2}{|c|}{ Hiperokzaliüri Nedenleri } \\
\hline Normokalsemik & Hiperkalsemik & Primer Hiperokzalüri & Sekonder Hiperokzalüri \\
\hline $\begin{array}{l}\text {-Idiopatik hiperklasiüri } \\
\text {-Distal renal tübüler asidoz tip } 1 \\
\text {-Diüretik ve steroid kullanımı } \\
\text {-Monogenik bozukluklar } \\
\text {-Medüller sünger böbrek } \\
\text {-Cushing Sendromu } \\
\text {-Immobilizasyon }\end{array}$ & $\begin{array}{l}\text {-Primer hiperparatiroidizm } \\
\text {-Hipo/Hipertiroidizm } \\
\text {-Metastatik kemik hastalığı } \\
\text { •Hipervitaminoz D veya A } \\
\text {-Adrenal yetmezlik ve steroid } \\
\text { fazlalığı } \\
\text {-Çocukluk çağının idiopatik } \\
\text { hiperkalsemisi } \\
\text {-Cushing sendromu } \\
\text {-Immobilizasyon }\end{array}$ & $\begin{array}{l}\text { Tip I primer hip- } \\
\text { erokzalüri } \\
\text { Tip II primer hip- } \\
\text { erokzalüri }\end{array}$ & $\begin{array}{l}\text { Diyetle okzalatın aşırı alınması } \\
\text { İnflamatuar bağırsak hastalığı } \\
\text { Kistik fibrozis } \\
\text { Pridoksin eksikliği } \\
\text { Yüksek doz vitamin C } \\
\text { Paranteral beslenme } \\
\text { Barsakta okzalat yıkıcı bakter- } \\
\text { ilerin (Oxalobacter formigenes) } \\
\text { yokluğu }\end{array}$ \\
\hline \multicolumn{2}{|l|}{ Hiperürikozüri Nedenleri } & \multicolumn{2}{|c|}{ Hipositratüri Nedenleri } \\
\hline \multicolumn{2}{|l|}{$\begin{array}{l}\text {-Diyetle fazla miktarda pürin alım } \\
\text {-Aşırı pürin üretilmesi ile ilgili boz } \\
\text { •HPRT1 eksikliği (Lesch-Nyhan se } \\
\text { •Fosforibozil pirofosfat aktivitesir } \\
\text { - Glikojen depo hastalığı tip } 1 \\
\text {-Myeloproliferatif - lenfoprolifera } \\
\text {-Tümör lizis sendromu } \\
\text {-Renal tübüler bozukluklar } \\
\text {-Herediter renal hiperürisemi } \\
\text {-Hiperürikozürik ilaçlar } \\
\text {-Diyabet } \\
\text {-Iddiopatik }\end{array}$} & \multicolumn{2}{|l|}{$\begin{array}{l}\cdot \text { Hiperkloremik met } \\
\cdot \text { Kronik ishal } \\
\cdot \text { Kistik fibrozis } \\
\cdot \text {-Renal tübüler asidd } \\
\cdot \text {-Karbonik anhidraz } \\
\cdot \text {-K+ eksikliği } \\
\text { •Enfeksiyon }\end{array}$} \\
\hline
\end{tabular}




\begin{tabular}{|c|c|c|c|}
\hline Metabolit & Yaş & $\begin{array}{l}\text { Solüt }(\mathrm{mg}) / \\
\text { kreatinin }(\mathrm{mg}) \text { oranı }\end{array}$ & 24 saatlik değer \\
\hline Kalsiyum & $\begin{array}{l}<12 \text { ay } \\
1-3 \text { yaş } \\
3-5 \text { yaş } \\
5-7 \text { yaş } \\
\geq 7 \text { yaş } \\
0-6 \text { ay } \\
7-24 \text { ay }\end{array}$ & $\begin{array}{l}<0,81 \\
<0,53 \\
<0,40 \\
<0,30 \\
<0,21 \\
<0,26-0,28 \\
<0,11-0,14\end{array}$ & $<4 \mathrm{mg} / \mathrm{kg}$ \\
\hline Okzalat & $\begin{array}{l}2-5 \text { yaş } \\
5-14 \text { yaş } \\
\geq 14 \text { yaş }\end{array}$ & $\begin{array}{l}<0,08 \\
<0,06-0,065 \\
<0,032\end{array}$ & \\
\hline Sitrat & $\begin{array}{l}\text { Erkek } \\
\text { Kız } \\
0-5 \text { yaş } \\
>5 \text { yaş }\end{array}$ & $\begin{array}{l}>0,42 \\
>0,25\end{array}$ & $\begin{array}{l}>365 \text { mg/1,73m2/gün } \\
>310 \mathrm{mg} / 1,73 \mathrm{~m} 2 / \text { gün }\end{array}$ \\
\hline Ürik asit & $\geq 2$ yaş & $<0,56 \mathrm{mg} / \mathrm{dl} / \mathrm{GFR}$ & $<815 \mathrm{mg}$ \\
\hline Magnezyum & $>2$ yaş & $>0,13$ & $>0,8 \mathrm{mg} / \mathrm{kg}$ \\
\hline
\end{tabular}

\section{Enfeksiyonlar}

Proteus, klebsiella, pseudomonas ve enterokoklar gibi üreaz üreten mikroorganizmalarla idrar yolu enfeksiyonu (IYE) geliştiğinde, taş oluşumuna yatkınlık oluşabilir. Bu enfeksiyonlarda ortaya çıkan taşlar ürenin üreaz tarafından parçalanmasıyla oluşan sitrüvitten meydana gelirler. Birikmeye, uzamaya ve renal kaliksleri doldurmaya meyillidirler. "Geyik boynuzu görüntüsü" denen görünümü oluşturabilirler. Ancak IYE görülen ve taş saptanan çocukların $\% 75^{\prime}$ inden fazlasında taş bileşiminin kalsiyum fosfat ya da kalsiyum oksalat olduğu belirlenmiştir [10].

\section{Konjenital ve Yapısal Anomaliler}

Yapılan araştırmalar üriner sistem taş hastalığı tespit edilen hastaların \%10-25'inde konjenital veya yapısal bir üriner sistem anomalisi olduğunu ortaya koymuştur. Bu anomaliler üriner sistemde darlığa yol açarak, idrar akışını yavaşlatır veya engellerler ve çeşitli kristallerin birikip taş oluşturabilmesine uygun bir ortam oluştururlar [11].

\section{Tanı}

Çocuklarda üriner sistem taşlarına bağlı olarak görülen obstrüksiyon, tekrarlayan IYE ve uygulanmak zorunda kalınan cerrahi işlemler nedeni ile böbrek hasarı geliştirebileceği için erken tanı morbiditenin azaltılmasında son derece önemlidir.

\section{Öykü}

Üriner sistem taş hastalıklarının kliniği çocukların yaş grubuna göre değişkenlik gösterir. Daha küçük yaşta çocuklar, nonspesifik karın ağrısı ve kusma, ateş gibi idrar yolu enfeksiyonu semptomlarıyla karşımıza gelebilirken, daha büyük çocuklar ve adölesanlarda kostovertebral açı hassasiyeti, mikroskopik veya makroskopik hematüri gibi daha yol gösterici semptomlarla karşımıza gelebilir. Tıkayıcı taşlar renal kolik tablosuyla, üreter alt ucuna yerleşen taşlar dizüri, ani sıkışma, mesane boynuna veya üretraya yerleşen taşlar damla damla işeme veya işeyememe tablosuyla karşımıza gelebilir. Asemptomatik taşlar da tesadüfen yapılan incelemelerde tanı alabilir [12].

İdrar yolu enfeksiyonu semptomlarıyla, nonspesifik karın ağrısıyla gelen çocuklarda ayrıntılı bir anamnez almak tanıda en büyük yol gösterici olacaktır. Aile öyküsü vakaların yaklaşık yarısında pozitif olduğu için, özellikle metabolik risk faktörleri olan çocuklarda belirleyicidir ve dikkatli incelenmelidir.

\section{idrar incelemesi}

Tanıya götürecek tetkiklerde ilk basamak tam idrar incelemesidir. Mikroskobik incelemede kristaller, kırmızı kan hücreleri, beyaz kan hücreleri görülebilir. İdrar incelemesinde mikroskopik hematüri görülen ani başlayan böğür ağrısı şikayeti olan hastada mutlaka taş akılda tutulmalıdır. Asidik idrarda ürik asit ve sistin taşlarının, bazik idrarda kalsiyum fosfatın daha kolay çöktüğü bilinmektedir, idrar analizi bu açıdan da yol gösterici olacaktır. IYE yanlış pozitif sonuçlara yol açabileceğinden ötürü ayırt edilmelidir. Üriner sistemde presipite olan kristaller idrar akım hızını azaltarak idrar yolu enfeksiyonuna zemin hazırlayabildikleri gibi, IYE de taş oluşumunun nedeni olabilir. Bu iki durum birbirinden klinik bulgular ve öykünün dikkatli incelemesiyle ayırt edilmelidir. Taş içeriğine ve sebebine göre uygulanan tedavi farklılık gösterecektir. 


\section{Metabolik inceleme}

Avrupa Pediatrik Üroloji Topluluğu tarafından taş analizi, 24 saatlik idrar tetkikleri, serum elektrolit, kan üre azotu, kreatinin, kalsiyum, fosfor, ürik asit, albümin ve parathormon ölçümleri taş saptanan bütün çocuklara yapılması önerilmektedir. Özellikle küçük çocuklarda taş hastalıklarında altta yatan metabolik bir neden ortaya çıkma ihtimali çok daha fazladır ve altta yatan metabolik nedenlere bağlı olan taşlarda tekrarlama oranı 5 kat daha fazladır, bu sebeple altta yatan nedene yönelik tedavinin yapılması ek morbiditeleri önlemek ve hayat kalitesini arttırmak açısından oldukça önemlidir. İdrarla atılan solütlerin ideal değerlerinin yaşa göre uygun sınırlarda değerlendirilmesinin yapılmasını ihmal etmemek gerekmektedir [13].

\section{Radyolojik Değerlendirme}

Taş şüphesinden sonra ilk tercih görüntüleme yöntemi olan ultrasonografi (US) 5 mm'den büyük taşlarda oldukça güvenilir bir görüntüleme yöntemidir. Taşın lokalizasyonuna, taş oluşumuna zemin hazırlayabilecek anatomik bozuklukları veya taş kaynaklı meydana gelebilen hidronefroz gibi komplikasyonları gösterme açısından yararlı bir yöntemdir. Ayrıca radyasyon maruziyeti olmaması ve uygulama kolaylığı da ultrasonografiyi tercih edilir bir görüntüleme yöntemi kılar. En sık görülen taş çeşitleri kalsiyum oksalat ve kalsiyum fosfat taşları kalsiyum içeriği nedeniyle radyoopak özellikte oldukları için direkt radyografik incelemede de üriner sistem taşlarının \%75'i görülebilir [14]. Ürik asit, amonyum ürat, ksantin taşları ise direkt grafide görülmez ve gözden kaçırılabilir. Direkt grafi ilk tercih görüntüleme yöntemi olmamakla beraber, asemptomatik hastalarda yapılan tesadüfi incelemelerde taşların bulunması açısından yararlı bir görüntülenme yöntemi olabilir.

\section{Intravenöz Pyelografi (IVP)}

İntravenöz Pyelografi toplayıcı sistemin anatomik anormalliklerini, obstrüksiyonun derecesini, taşın yerleşimini belirlemek için kullanılabilir. Ancak kontrast madde kullanımına bağlı reaksiyonlar ve nefrotoksisite gelişme riski olduğundan kullanımı sınırlıdır [14].

Kontrastsız Bilgisayarlı Tomografi

Küçük taşlar ve üreter taşlarını görüntülemede kontrastsız bilgisayarlı tomografi US'den daha duyarlı ve spesifik olmakla beraber önemli derecede radyasyon maruziyeti nedeniyle kullanımı kısıtlıdır. Düşük dozlu tomografik inceleme (30 mAs) vücut kitle indeksi $<30$ olan hastalarda $>3 \mathrm{~mm}$ olan üreter taşlarını standart bilgisayarlı tomografi (180 mAs) ile aynı derecede gösterebilmektedir [15].

\section{Tedavi ve İzlem}

Üriner sistem taşlarının tedavisindeki temel hedefler taşın ve taşa bağlı gelişen enfeksiyon ve obstruksiyon gibi komplikasyonların ortadan kaldırılması, tekrar taş oluşumunun önlenmesi, böbrek fonksiyonlarının korunması, enfeksiyonların önlenmesi ve en önemlisi özellikle çocukluk çağında altta yatan anatomik ve metabolik problemlerinin düzeltilmesi olmalıdır (Tablo 3) [16].

Üriner sistem taşı olan çocukların yaklaşık \%50'si renal kolikle hastaneye başvururlar. İlk aşama ağrının giderilmesi, varsa tıkanıklık gibi acil durumların değerlendirilmesi olmalıdır. Gerekirse acil müdahalenin yapılmasının ardından tedavinin ilk basamağını taş çeşidinden bağımsız olarak, sıvı alımı oluşturur. Bol sıvı alımı taş oluşumuna zemin hazırlayan kristallerin çözülmelerini ve atılmalarını kolaylaştırır. Asemptomatik, milimetrik taşlarda tedavi gerekmeyebilir. US ile takibi yeterlidir. Üriner sistem taş hastalığı olan bir çocuğun konservatif olarak izlenebilmesi için ağrısı, altta yatan bir metabolik bozukluğu, taş oluşumuna zemin hazırlayacak bir anatomik bozukluğu, obstrüksiyon veya enfeksiyonun olmaması gerekir. Tedavi gerektiren çocuklarda ise önemli olan altta yatan nedene yönelik tedaviyi sağlamak, tekrarların olmasını önlemek ve böbrek fonksiyonlarının korunmasını sağlamaktır. Taş çeşidinin ne olduğu bulunduktan sonra beslenmenin de buna göre düzenlenmesi gerekir. Tuz ve hayvansal proteinlerin aşırı tüketimi ise taş çeşidinden bağımsız olarak kısıtlanmalıdır. Hiperkalsiüride potasyumdan zengin, düşük sodyum içeren ve yaşa uygun protein diyeti önerilir. Hiperokzalüri varsa okzalat ve hiperürikozüride pürin içeriği düşük gıdalar alınmalıdır. Limon ve portakal suyundan hipositratüride yarar görülebilir. Çocuk hastalarda büyüme gelişme süreci devam etmekte olduğundan diyet uygulanması oldukça hassas bir konu olup dikkatli davranılmalıdır. Düşük proteinli diyetlerin erişkinlerde taş oluşma riskini azalttığı gösterilmiş olsa da çocuklara uyarlanması hiçbir şekilde önerilmemelidir [17].

Taş oluşumunu arttırdığı bilinen besinlerin kontrollü tüketilmesi gerekmektedir. Bu özellikteki başlıca besinler, aşırı hayvansal protein tüketimi (>1,0 g/kg/gün kırmızı et, süt ve süt ürünleri), tuz, ıspanak, karbonhidrat (sukroz ve fruktoz, şekerli ve unlu mamuller), sakatat ürünleri ve çikolatadır. Kalsiyum, sodyum (>1.5 gr/gün tuz), okzalat, C-vit ve D-vit alımı taş olu $\neg$ şumu için ciddi risk faktörleridir. Aşırı hayvansal protein alımı hiperkalsiüri ve hipositratüriye neden olarak taş oluşumuna predispozisyon oluşturur. Ancak çoğu zaman hiperkalsürinin diyetle bir ilişkisi yoktur. Bu yüzden çocuklarda kalsiyum tüketiminin kısıtlanması kesinlikle önerilmemektedir. 
Bu konuda toplumda yaygın ve yanlış olarak aksi bir kanı mevcut olduğundan aileler özellikle bilgilendirilerek uyarılmalıdır. Tuz ve karbonhidrat alımı kısıtlanmalıdır. Sebze ve meyve ağırlıklı liften zengin beslenme önerilmektedir [17].

Altta yatan enfeksiyon veya taş sebebiyle ortaya çıkan enfeksiyon varsa araştırılmalı ve mutlaka öncelikli olarak tedavi edilmelidir. Üriner sistemde enfeksiyonun devamlı olarak kalması, taş oluşumu açısından elverişli bir ortam yaratacak ve tedaviye rağmen bir kısır döngü oluşturacaktır.

Taş gelişimine zemin hazırlayan anatomik bozukluklar varsa mutlaka cerrahi olarak düzeltilmelidir.

Medikal tedavinin başarı sağlayamadığı durumlarda ise üriner sistem taş hastalığı taşın cinsi ve büyüklüğüne göre seçilen extracorporeal shockwave lithotripsy (taş kırma), endoürolojik işlemler, açık cerrahi ve lapa $\neg$ roskopik yöntemler gibi cerrahi yöntemle tedavi edilir [18].

\begin{tabular}{|c|c|c|}
\hline Taş Tipi & Öneriler & İlaçlar \\
\hline Tüm taş tipleri & $\begin{array}{l}\text { Sıvı alımının arttırılması } \\
\text { İnfant: } 750 \mathrm{ml} / \text { gün } \\
\text { <5yaş: } 1000 \mathrm{ml} / \text { gün } \\
\text { 5-10 yaş: } 1500 \mathrm{ml} / \text { gün } \\
\text { >10 yaş: } 2000 \mathrm{ml} / \text { gün }\end{array}$ & \\
\hline Sitrüvit taşı & İnfekte taşın çıkarılması & \\
\hline Sistinüri & Gece-gündüz devamlı yüksek sıvı tüketimi & $\begin{array}{l}\text {-Potasyum sitrat } \\
\text {-Kaptopril } \\
\text {-Tiopronin (infantlarda kullanılmaz) } \\
\text {-D-penisillamin (infantlarda kullanılmaz) }\end{array}$ \\
\hline Hipositratüri & Limon ve portakal suyu & -Potasyum sitrat \\
\hline Hiperürikozüri & Pürinden kısıtlı diyet & $\begin{array}{l}\text {-Potasyum sitrat } \\
\text {-Allopurinol }\end{array}$ \\
\hline Hiperokzaluri & $\begin{array}{l}\text {-Sekonderhiperokzaluri için okzalattan fakir diyet } \\
\text { Okzalattan zengin gıdalar: pancar, kereviz, pırasa, bamya, } \\
\text { kabak, taze fasulye, biber, çay, yulaf, kızılcık, kakao, çikolata } \\
\text {-Yüksek doz C vitamini tüketiminden kaçınılmalı }\end{array}$ & $\begin{array}{l}\text {-Klorotiazid } \\
\text {-Potasyum sitrat } \\
\text {-Piridoksin (Vit B6) } \\
\text {-Modüretik (HCTZ+amilorid) }\end{array}$ \\
\hline Hiperkalsiüri & $\begin{array}{l}\text { Yüksek potasyum, düşük sodyum ve yeterli miktarda protein, } \\
\text { kalsiyum ve okzalat alımı (aşırı tüketimden kaçınılmalı) }\end{array}$ & $\begin{array}{l}\text {-Klorotiazid } \\
\text {-Potasyum sitrat } \\
\text {-Modüretik }\end{array}$ \\
\hline
\end{tabular}

\section{Sonuç}

Üriner sistem taş hastalıklarının insidansı yıllar geçtikçe artış göstermektedir ve ciddi bir sağlık problemi oluşturmaktadır $\mathrm{Bu}$ hastalıklar, asemptomatik bir şekilde takip edilebileceği gibi böbrek yetmezliğiyle sonuçlanabilecek kadar ağır kliniklerle de karşımıza gelebilmektedir. Bu kadar geniş bir klinik spektrumda karşımıza gelebilecek bu hastalıkların mutlaka ayırıcı tanıda akılda tutulması gerekmektedir. Aile öyküsü ve altta yatan metabolik ve anatomik durumların taşa yarattığı yatkınlık daima göz önünde bulundurulmalı ve her biri araştırıldıktan sonra altta yatan nedene göre tedavi düzenlenmelidir.

\section{Maddi Destek ve Çıkar İlişkisi}

Çalışmayı maddi olarak destekleyen kişi/kuruluş yoktur ve yazarların çıkara dayalı bir ilişkisi yoktur.

\section{Kaynaklar}

1. Ece A, Özdemir E, Gürkan F, et al. Characteristics of pediatric urolithiasis in south-east Anatolia. Int J Urol 2000; 7: 330-4.

2. Sirin A, Emre S, Alpay $\mathrm{H}$, et al. Etiology of chronic renal failure in Turkish children. Pediatr Nephrol 1995; 9: 549-52.

3. Önen A. Çocuklarda Üriner Sistem Taş Hastalığı, Çocuk Cerrahisi Derg 2013; 27: 8-32.

4. Novak TE, Lakshmanan Y, Trock BJ, Gearhart JP, Matlaga BR. Sex prevalence of pediatric kidney Stone disease in the United States: an epidemiologic investigation. Urology 2009; 74: 104.

5. Dwyer ME, Krambeck AE, Bergstralh EJ, Milliner DS, Lieske JC, Rule AD. Temporal trends in incidence of kidney stones among children: a 25-year population based study. J Urol 2012; 188: 247.

6. Elmacı AM, Ece A, Akın F. Pediatric urolithiasis: metabolic risk factors and follow-up results in a Turkish region with endemic stone disease. Urolithiasis 2014; 42: 421-6. 
7. Coward RJ, Peters CJ, Duffy PG, et al. Epidemiology of pediatric renal stone disease in the UK. Arch Dis Child 2003; 88: 962.

8. Yılmaz A, Yürük Yıldırım Z. Çocuklarda Üriner Sistem Taş Hastalığına Yaklaşım. Çocuk Derg 2013; 13: 154-9.

9. Baştuğ F. İnfantlarda Üriner Sistem Taş Hastalığı: Etiyoloji ve Tedavi, Endoürol Bül 2013; 6: 143-51.

10. Gleeson MJ, Griffith DP. Struvite calculi. BJU 1993; 71: 503-11.

11. Sternberg K, Greenfield SP, Williot P, Wan J SO. Urolithiasis in pediatric patients: a single center study of incidence, clinical presentation and outcome, J Urol 2005; 174: 1711.

12. McKay CP. Renal Stone disease. Pediatr Rev 2010; 31: 179-88.

13. Pietrow, PK, Pope JC, Adams MC, Shyr Y, Brock JW. Clinical outcome of pediatric stone disease. J Urol 2002; 167: 670-3.
14. Hoppe B, Kemper MJ. Diagnostic examination of the child with urolithiasis or nephrocalcinosis. Pediatr Nephrol 2010; 25: 403-13.

15. Nicoletta JA, Lande MB. Medical evaluation and treatment of urolithiasis. Pediatr Clin N Am 2006; 53: 479-91.

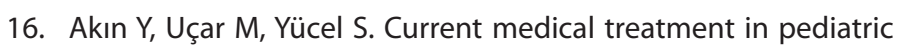
urolithiasis. Turk J Urol 2013; 39: 253-63.

17. Agarwal MM, Singh SK, Mavuduru R, Mandal AK. Preventive fluid and dietary therapy for urolithiasis: An appraisal of strength, controversies and lacunae of current literature, Indian J Urol 2011; 27: 310-9.

18. Ataç F, Bostancı Y, Germiyanoğlu RC. Pediatrik endoskopik üroloji'de son durum. Endoürol Bül 2014; 7: 57-61. 